\title{
MENUMBUHKAN EMPATI DAN PERILAKU PROSOSIAL TERHADAP ANAK USIA DINI DALAM MENANGGAPI PELAJARAN ISU DUNIA NYATA
}

\author{
Salmaa Mardatillah Syafitri \\ Universitas PGRI Madiun \\ Salmasyafitri1003@gmail.com
}

\begin{abstract}
Abstrak
Sikap dan tindakan yang selalu ingin memberi bantuan perlu dikembangkan pada diri anak, terutama anak prasekolah. Peduli sosial perlu dikembangkan agar anak tidak memiliki sifat negatif, seperti sombong, acuh tak acuh, individualisme, masa bodoh terhadap masalah sosial, dan lunturnya budaya gotong - royong. Peduli sosial adalah sikap dan tindakan yang selalu ingin memberi bantuan pada orang lain dan masyarakat yang membutuhkan. Dari sinilah kepedulian sosial menuntut kepada setiap individu agar mampu memperhatikan lingkungan tempat tinggalnya atau masyarakat. Tujuan dari artikel ini adalah untuk mengeksplorasi empati dan perilaku prososial dalam masalah dunia nyata. Menggunakan sebuah pendekatan kualitatif, tujuh siswa terlibat dalam enam sesi kelompok atau individu kegiatan termasuk lima sesi menanggapi sketsa video yang diperagakan masalah dunia nyata terkait dengan hak-hak anak (kemiskinan, perang, pekerja anak, lingkungan, atau penyakit) dan satu sesi untuk refleksi. Analisis data mengungkapkan empati emosional termasuk tekanan empati, kemarahan empatik, dan disonansi emosional. Kognitif empati diekspresikan melalui pengambilan peran, perbandingan, dan identifikasi. Ekspresi empati emosional dan kognitif, dan niat prososial terkait dengan nilai-nilai moral dan penilaian.
\end{abstract}

Kata Kunci : Empati, Dunia Nyata, Prososial, Peduli Sosial, Pembelajaran.

\section{PENDAHULUAN}

Perilaku empati dan prososial memainkan peran penting dalam pemahaman anak-anak terhadap orang lain dan dunia di sekitar mereka. Mengajar siswa sekolah dasar selama lebih dari satu dekade di Madiun, menghadapi peningkatan jumlah siswa yang tampaknya kurang memiliki kemauan untuk mencoba memahami orang lain, yang sering menimbulkan konflik di ruang kelas mereka. Fenomena ini sering disebut (Kelas Runtuh). Meningkatnya kekerasan dan menurunnya rasa hormat terhadap orang lain, seperti teman sebaya dan guru, menimbulkan konflik di kelas dan kesulitan untuk guru untuk mendidik anak-anak untuk bertindak dengan cara yang konsisten dengan perilaku prososial. Selain itu, fenomena ini juga terkait dengan banyak masalah besar seperti intimidasi, kekerasan sekolah, penolakan, dan perilaku agresif, tidak hanya di Madiun, tetapi juga di kota ataupun negara di seluruh dunia. Mempelajari empati sebagai alat yang mungkin untuk menyelesaikan konflik antar pribadi, kita dapat memperoleh wawasan yang lebih baik tentang dinamika kontinum umum mandiri terhadap anak - anak.

Anak usia dini adalah sosok individu yang sedang menjalani suatu proses perkembangan denganpesat dan fundamental baik kehidupan selanjutnya. Anak usia dini sendiri adalah mereka yang memilikirentan usia antara $0-8$ tahun ada yang mengatakan 0 - 6 tahun. Pada masa ini terjadilah proses pertumbuhan dan perkembangan dalamberbagai aspek, salah satu diantaranya adalah aspek dalam interaksi sosial.

Psikolog humanistik telah bertahun tahun menekankan perlunya mengkonsep kembali egosentris kita pengertian tentang 
diri. Perasaan diri yang terbatas ini mungkin merupakan penularan psiko - filosofis dari mana sebagian besar masalah manusia seperti kekerasan, krisis ekologi, atau perang. Namun, banyak filsuf dan psikolog barat menjunjung tinggi rasa transpersonal melalui "Realisasi Mendalam", yang menunjukkan bahwa mempromosikan identitas psikologis atau kesadaran diri yang le bih besar memungkinkan untuk menghubungkan kembali orang dan menggerakkan mereka ke arah sistem nilai yang lebih transpersonal. Meskipun mungkin terlihat sangat tinggi abstrak, sistem transpersonal menggambarkan inti dari masalah sosial yang tidak dialami hanya di ruang kelas tetapi juga di semua kelompok sosial.

Berdasarkan fondasi filosofis sosial, studi ini mengalihkan perhatian dari pribadi ke dunia masalah. Studi ini berfokus pada empati anak dan niat prososial terkait empati menanggapi pelajaran masalah dunia nyata, terutama masalah dengan hak anak-anak. Tujuan dari artikel ini adalah untuk memahami jika pengetahuan tentang masalah dunia membantu anak-anak menyadari yang lebih besar gambar dan untuk mengeksplorasi jika masalah kehidupan nyata membantu anak-anak yang berpotensi memahami orang lain ' perasaan (empati), berbagi hal, dan saling membantu (perilaku prososial).

\section{PEMBAHASAN}

\section{Empati dan Prososial}

Definisi empati mencakup berbagai keadaan emosi, termasuk merawat orang lain dan memiliki keinginan untuk membantu mereka; mengalami emosi yang cocok dengan emosi orang lain, membedakan apa yang dipikirkan atau dirasakan orang lain, dan membuat perbedaan yang tidak terlalu berbeda antara diri dan yang lain. Hal ini juga dapat dipahami sebagai memiliki keterpisahan dalam mendefinisikan diri sendiri dan yang lain menjadi kabur. Ini juga merupakan kemampuan untuk merasakan dan berbagi emosi orang lain. Beberapa percaya bahwa empati melibatkan kemampuan untuk mencocokkan emosi orang lain, sementara yang lain percaya bahwa empati melibatkan bersikap lembut terhadap orang lain.

Memiliki empati dapat mencakup memiliki pemahaman bahwa ada banyak faktor yang masuk ke dalam pengambilan keputusan dan proses berpikir kognitif. Pengalaman masa lalu memiliki pengaruh pada pengambilan keputusan saat ini. Memahami hal ini memungkinkan seseorang untuk memiliki empati terhadap individu yang terkadang membuat keputusan yang tidak masuk akal terhadap masalah yang akan ditanggapi sebagian besar individu dengan respons yang jelas. Rumah yang rusak, trauma masa kanak - kanak, kurangnya pengasuhan anak, dan banyak faktor lainnya dapat memengaruhi koneksi di otak yang digunakan seseorang untuk membuat keputusan di masa depan.

Martin Hoffman adalah seorang psikolog yang mempelajari perkembangan empati. Menurut Hoffman, setiap orang dilahirkan dengan kemampuan merasakan empati. Belas kasihan dan simpati adalah istilah yang terkait dengan empati. Definisi bervariasi, berkontribusi terhadap tantangan mendefinisikan empati. Belas kasih sering didefinisikan sebagai emosi yang kita rasakan ketika orang lain membutuhkan, yang memotivasi kita untuk membantu mereka. Simpati adalah perasaan peduli dan pengertian bagi seseorang yang membutuhkan. Beberapa di antara mereka termasuk dalam simpati, keprihatinan empatik, perasaan prihatin terhadap yang lain, di mana beberapa sarjana menyertakan keinginan untuk melihat mereka lebih baik atau lebih bahagia. Empati juga berbeda dari rasa kasihan dan penularan emosional. Kasihan adalah perasaan bahwa seseorang merasa terhadap orang lain yang mungkin dalam kesulitan atau membutuhkan bantuan karena mereka tidak dapat memperbaiki 
masalah mereka sendiri, sering digambarkan sebagai "merasa kasihan" untuk seseorang. Penularan emosi adalah ketika seseorang (terutama bayi atau anggota gerombolan) secara imitatif "menangkap" emosi yang ditunjukkan orang lain tanpa harus menyadari bahwa ini sedang terjadi.

Empati umumnya dibagi menjadi dua komponen utama :

\section{Empati afektif}

Empati afektif, juga disebut empati emosional yang merupakan kapasitas untuk merespons dengan emosi yang sesuai dengan kondisi mental orang lain. Kemampuan kita untuk berempati secara emosional didasarkan pada penularan emosi dipengaruhi oleh keadaan emosi atau rangsangan orang lain. Empati afektif dapat dibagi lagi ke dalam skala berikut : Perhatian empatik : Distress pribadi dan Distress pribadi.

Empati kognitif : kapasitas untuk memahami perspektif atau kondisi mental orang lain. Istilah empati kognitif dan teori pikiran atau mentalisasi sering digunakan secara sinonim, tetapi karena kurangnya penelitian yang membandingkan teori pikiran dengan jenis empati, tidak jelas apakah ini setara.

2. Empati kognitif dapat dibagi menjadi beberapa skala berikut :

a) Pengambilan perspektif : kecenderungan untuk secara spontan mengadopsi perspektif psikologis orang lain.

b) Fantasi : kecenderungan untuk mengidentifikasi diri dengan karakter fiksi.

c) Empati taktis (strategis) : penggunaan pengambilan perspektif secara sengaja untuk mencapai tujuan tertentu yang diinginkan.

\section{Somatik}

Empati somatik adalah reaksi fisik, mungkin berdasarkan respons neuron cermin, dalam sistem saraf somatik. Somatik mengacu pada tubuh, secara khusus terpisah dari pikiran. Empati somatik berfokus pada respons fisik terhadap situasi tertentu yang terkait dengan orang lain.

\section{Perilaku Prososial}

Perilaku Prososial atau niat untuk memberi manfaat pada orang lain, adalah perilaku sosial yang "memberi manfaat kepada orang atau masyarakat secara keseluruhan, seperti membantu, berbagi, menyumbang, bekerja sama, dan menjadi sukarelawan. Mematuhi peraturan dan menyesuaikan diri dengan perilaku yang diterima secara sosial (seperti berhenti pada tanda "Stop" atau membayar bahan makanan) juga dianggap sebagai perilaku prososial. Tindakan - tindakan ini dapat dimotivasi oleh empati dan kepedulian terhadap kesejahteraan dan hak orang lain, serta untuk kepedulian egois atau praktis, seperti status sosial atau reputasi seseorang, harapan untuk timbal balik langsung atau tidak langsung, atau kepatuhan pada persepsi seseorang sistem keadilan. Mungkin juga dimotivasi oleh altruisme, meskipun keberadaan altruisme murni agak diperdebatkan, dan beberapa berpendapat bahwa ini jatuh ke ranah debat filosofis daripada psikologis. Bukti menunjukkan bahwa pro sosialitas adalah pusat kesejahteraan kelompok sosial di berbagai skala, termasuk sekolah. Perilaku prososial di kelas dapat memiliki dampak signifikan pada motivasi siswa untuk belajar dan berkontribusi ke kelas dan komunitas yang lebih besar. Empati adalah motif kuat dalam memunculkan perilaku prososial, dan memiliki akar evolusi yang dalam.

Perilaku prososial memupuk sifat - sifat positif yang bermanfaat bagi anak-anak dan masyarakat. Ini membantu banyak fungsi yang bermanfaat dengan meningkatkan produksi liga apa pun dan skala organisasinya. Psikolog evolusi menggunakan teori seperti teori seleksi keluarga dan kebugaran inklusif sebagai penjelasan mengapa kecenderungan perilaku prososial diturunkan secara generasi, 
menurut kebugaran evolusi yang diperlihatkan oleh mereka yang terlibat dalam tindakan prososial. Mendorong perilaku prososial juga mungkin memerlukan penurunan atau penghapusan perilaku sosial yang tidak diinginkan.

\section{Pengembangan Empati dan Prososial}

Baron dan Byrne (2005: 111) yang menyatakan bahwa empati merupakan kemampuan untuk merasakan keadaan emosional orang lain, merasa simpatik dan mencoba menyelesaikan masalah, dan mengambil perspektif orang lain. Arwani (2002: 56) menyatakan empati terhadap pasien merupakan perasaan dan "pemahaman" dan "penerimaan" perawat terhadap pasien mengenai apa yang dialami pasien dan kemampuan merasakan "dunia pribadi pasien". Empati merupakan sesuatu yang jujur, sensitive dan tidak dibuat - buat didasarkan atas apa yang dialami orang lain. Namun, ada kesepakatan luas bahwa domain empati mengandung dimensi kognitif dan emosional, dan itu empati emosional adalah respons emosional terhadap suatu objek dalam kesusahan. Jadi, empati, dalam penelitian ini, mencakup kemampuan dan rangsangan spontan untuk merasakan emosi dan pikiran orang lain dan perasaan kemampuan kognitif dan emosional untuk memahami pandangan, situasi, dan peran orang lain.

Empati telah diterima secara luas sebagai blok pembangun fundamental bagi kesehatan sosial dan fungsi emosional pada anak-anak dan remaja terutama karena kaitannya dengan perilaku prososial, kompetensi sosial dan hubungan negatifnya dengan perilaku antisosial dan agresif (Lovett \& Sheffeild, 2007). Banyak ahli saraf juga telah menunjukkan bahwa ada hubungan di antara keduanya aktivitas saraf, sifat empati dan aktivitas saraf terkait dengan empati bantuan dunia nyata (Rameson, Morelli, \& Lieberman, 2012).
Dalam beberapa hari pertama kehidupan, bayi telah didokumentasikan sebagai menanggapi orang lain. emosi, yang menunjukkan kecenderungan biologis untuk mengalami empati. Di tahun kedua kehidupan, anak-anak memiliki kapasitas untuk menunjukkan empati melalui perilaku prososial melalui reaksi emosional terhadap perasaan ibu mereka. Anak-anak berusia dua hingga tiga tahun semakin sadar perasaan orang lain dan telah menyadari bahwa perasaan dan persepsi ini dapat berbeda dari perasaan mereka sendiri.

Pada usia ini, anak-anak mengekspresikan "tekanan simpatik". Di akhir masa kanak - kanak, Namun, anakanak lebih empati dan telah mengakui bahwa pengalaman kesusahan tidak hanya situasi khusus, tetapi juga bagian dari kehidupan. Sementara itu, penelitian lain menunjukkan bahwa anak-anak berusia tujuh hingga delapan tahun mendasarkan interpretasi mereka pada emosi orang lain pada diri mereka sendiri emosi, sedangkan perasaan anak-anak sembilan hingga dua belas tahun didasarkan pada pengalaman mereka, dan mereka yang berusia di atas tiga belas tahun menggunakan pengalaman dan strategi pengambilan peran untuk memahami orang lain (Catherine \& Schonert-Reichl, 2010)

Artikel ini telah menemukan bahwa anak-anak memiliki kemampuan untuk mengekspresikan empati dan bertindak secara prosedural, yang mana dapat membuat upaya untuk mendorong empati sebagai upaya yang bermanfaat. Hoffman (2000), misalnya, menyatakan bahwa anak-anak memiliki kemampuan untuk mentransfer empati yang berpusat pada diri sendiri ke empati yang berpusat pada yang lain dengan menggunakan pemikiran non - egosentris. Di sisi lain, anak-anak yang sangat muda memiliki sedikit kemampuan pengambilan perspektif; mereka sering merasa takut dan tertekan, dan dengan mudah menjadi sedih bagi para korban. Anak-anak merasakan rasa 
sakit orang lain seperti rasa sakit mereka sendiri, yang membuat mereka sering merasa lebih tertekan daripada orang dewasa (Barnett, 1987). Piaget (1965) berpendapat, anak-anak di masa kecil dapat berkomunikasi secara efektif dan memahami dan merasakan emosi dan persepsi orang lain. Anak-anak juga dapat merasakan perilaku atau situasi orang lain, yang dapat menjadi kunci untuk mengembangkan dan mendorong perilaku prososial (Piaget). Selanjutnya, (Vygotsky) dan (Bruner) berpendapat bahwa anak-anak memiliki potensi untuk memahami mereka lingkungan Hidup. Karenanya, menyediakan perancah yang tepat dapat membantu anakanak mengembangkannya potensi - kognitif, sosial, moral, dan emosional.

\section{Bentuk Kepedulian Sosial yang dapat di Ajarkan kepada Anak}

Bentuk - bentuk kepedulian sosial dapat dibedakan berdasarkan lingkungan. Lingkungan yang dimaksud merupakan lingkungan dimana seseorang hidup dan berinteraksi dengan orang lain yang biasa disebut lingkungan sosial. Menurut Elly $\mathrm{M}$. Setiadi, lingkungan sosial merujuk pada lingkungan dimana seseorang melakukan interaksi sosial, baik dengan anggota keluarga, teman, dan kelompok sosial lain yang lebih besar (2012: 66). Buchari Alma, dkk (2010: 205-208) membagi bentuk-bentuk kepedulian berdasarkan lingkungannya, yaitu: a. Lingkungan Keluarga Keluarga merupakan lingkungan sosial terkecil yang dialami oleh seorang manusia. Lingkungan inilah yang pertama kali mengajarkan manusia bagaimana berinteraksi.diajarkan berbagai peran yang nantinya akan menjadi indentifikasi dirinya, selain itu pula saat melakukan interasi sosial anak akan memperoleh berbagai informasi yang ada disekitarnya

Ada begitu banyak nilai - nilai kebaikan yang sebaiknya ditanamkan kepada diri anak, yakni kepedulian terhadap sesama. Seiring dengan berkembangnya waktu dan zaman, rasa kepedulian banyak manusia terhadap sesamanya mulai banyak berubah dan meluntur, sehingga dengan menanamkan rasa peduli terhadap sesamanya, maka di masa depan lingkungan anak anda tumbuh dan hidup tetap menjunjung tinggi rasa kepedulian yang besar bagi sesama.

Sikap sayang sesama dapat dilatih kepada anak dengan cara, misalnya, memberi tahu anak bagaimana harus bersikap saat berteman. Mereka juga harus diajarkan untuk mengutarakan perasaan dengan kata-kata. Bagi anak, hal itu sangat penting karena saat anak anak segala sesuatu ingin diketahui.Hal lain yang harus diajarkan orangtua kepada anak adalah mengajarkan mereka untuk menolak perilaku yang bertentangan dengan kasih sayang salah satunya yaitu mengejarkan kepedulian terhadap sesama.

\section{Pengaruh Sosial - Budaya dan Perbedaan Gender Mengenai Empati dan Prososial Pengembangan.}

Konsep empati memiliki tradisi filosofis sebagai keduanya sosial norma dan sebagai nilai individu yang penting. Salah satu agen pemodelan social - budaya yang paling penting saat ini adalah media, dalam banyak ragamnya formulir. Televisi, misalnya, memainkan peran penting dalam sebagian besar pendidikan dan sosialisasi anak-anak. Dapat dikatakan bahwa itu tidak hanya membantu membentuk karakter anak-anak, tetapi juga sistem nilai dan filosofi mereka. Paparan media, program televisi, film, iklan, berita, dan permainan komputer / video memberikan perpaduan yang baik (mis. pendidikan) dan program buruk (kekerasan) yang dapat memengaruhi anak - anak dalam hal perilaku yang bertanggung jawab secara sosial atau perilaku kekerasan, tidak toleran, atau anti - sosial. Apalagi yang dibuat sedemikian rupa pseudo - reality, seringkali menjadi tidak mungkin bagi seorang anak

website: http://jurnal.untan.ac.id/index.php/jvip email: jurnalvisi@untan.ac.id 
untuk membedakan yang nyata dari yang tidak nyata, khususnya untuk anak kecil.

Secara umum, gender yang berkaitan dengan empati dan perilaku prososial kontroversial. Banyak sarjana berpendapat bahwa anak perempuan (anak-anak) memiliki skor empati yang lebih tinggi dan dianggap lebih empati daripada anak laki-laki, sedangkan ahli saraf berpendapat bahwa tidak ada perbedaan gender (Eliot, 2009). Namun, ahli saraf dan para ilmuwan kognitif sepakat bahwa anak perempuan disosialisasikan agar lebih selaras dengan sosial mereka lingkungan (Eliot, 2009) berpendapat bahwa empati anak perempuan adalah terbatas pada teman dan bukan untuk kerja sama dengan teman sebaya.

\section{Perkembangan Empati dan Prososial Menuju Isu dunia nyata}

Saya menemukan hubungan positif antara empati dan niat dan perilaku prososial dalam hal ini populasi sampel. Tampaknya ketika seseorang mengalami empati, dia juga mengekspresikannya niat untuk membantu. Sementara beberapa anak lebih ekspresif secara emosional, yang lain memperlihatkan pendekatan yang lebih praktis dan mengambil perspektif. Namun, kedua kelompok anak-anak itu menunjukkan niat prososial. Anak-anak tampaknya mengerti bahwa mereka harus membantu atau memberikan sesuatu kepada para korban. Niat prososial yang diamati ditampilkan dalam penelitian ini adalah aneka dan praktis. Karena sketsa video difokuskan terutama pada anak-anak, tema prososial seperti mensponsori anak-anak, menyumbangkan uang / sumber daya, atau bergabung dengan organisasi yang didominasi. Dinyatakanniat cenderung cukup realistis dan memiliki potensi nyata untuk diterjemahkan menjadi "tindakan nyata". Ini niat tidak hanya memberikan pandangan yang menarik ke dunia yang ideal tetapi juga didokumentasikan saran spesifik tentang apa yang mungkin dibutuhkan korban untuk mengatasi masalah tersebut. Misalnya, anakanak menyarankan agar memberi dan mensponsori sebagai salah satu cara untuk membantu para korban. Sementara sebagian besar dari ini ide menggemakan saran yang dibuat dalam video UNICEF (menyumbangkan uang), gagasan lain seperti mengorganisir protes, berharap dunia tanpa perang atau menyewa pengacara perang adalah asli. "Membuat" korban menjadi sehat dan "memberi" kebahagiaan bagi mereka dan kedamaian tampaknya menjadi landasan moral dalam rasa keadilan anak-anak ini.

Memiliki kesempatan untuk berurusan dengan masalah-masalah dunia nyata tampaknya membantu anak-anak mengeksplorasi hal-hal baru dunia dan halhal baru. Sesi menawarkan kesempatan bagi anak - anak untuk memahami situasi, gaya hidup, kebutuhan, harapan dan hak asasi manusia korban. Mereka terlibat secara aktif diskusi dan sering menggunakan modus operandi kognitif dan etika untuk 'memecahkan' masalah dunia nyata. Terkena beberapa masalah dunia memberi anak-anak banyak kesempatan untuk dipikirkan diri mereka sendiri dan orang lain. Pada tingkat tertentu, penelitian ini mungkin membantu mereka menyadari betapa beruntungnya mereka mereka benar-benar tumbuh di lingkungan dan masyarakat yang umumnya aman dan terlindungi.

\section{Implikasi : Mendorong Perilaku Empati dan Prososial sebagai Pendidikan Moral}

Artikel ini mengungkapkan temuan terkait dengan perkembangan anak dalam hal empati (emosi dan kognisi), moralitas, tanggung jawab sosial dan keterlibatan sosial. Itu anak-anak usia menengah tampaknya umumnya memiliki kemampuan untuk terlibat dalam pengambilan peran meningkatkan kesadaran mereka tentang orang lain. Meskipun anak - anak terlibat dalam pengambilan peran, perancah bisa 
memainkan peran penting dalam mendorong empati kognitif mereka. Membahas contoh spesifik dan mengizinkan anak untuk bertindak (membantu) dapat membentuk suatu bentuk perilaku prososial. Artikel ini mengungkapkan bukti penilaian moral anak anak serta keinginan kuat mereka untuk membantu. Dalam penelitian ini juga memperlihatkan kemampuan untuk melihat dan melakukan "hal yang benar". Misalnya, anak - anak menunjukkan penilaian moral, penalaran, dan nilai-nilai moral yang tinggi dengan :

a). Memprotes;

b). Menilai secara moral;

c). Mengembangkan filosofi hidup

positif; dan

d). Menyadari pentingnya lingkungan.

Ada kemungkinan bahwa seiring bertambahnya usia anak - anak ini dan menjadi lebih berpengalaman dengan altruisme dan moralitas, mereka akan mengembangkan nilai - nilai yang mencerminkan beberapa konsep dunia nyata dari penelitian ini tentang perilaku membantu. Dengan demikian, memberi lebih banyak anak kesempatan untuk mengamati mereka yang membantu orang lain dan mereka yang membutuhkan bantuan menawarkan cara untuk menjembatani kesenjangan yang tampaknya tidak dapat diatasi antara tanggung jawab sosial dan perilaku prososial. Dengan begitu, semakin banyak anak dapat menyadari bahwa ada orang lain yang mereka harus memasukkan dalam gambar dunia pribadi mereka, dan, seperti anak-anak dalam kelompok ini, ungkapkan kemampuan atau setidaknya potensi berurusan dengan masalah dunia melalui lisan dan tulisan pengalaman. Jenis refleksi dan realisasi ini mempromosikan niat prososial, yang menunjukkan potensi yang lebih besar untuk pengembangan lebih lanjut. Perkembangan ini terjadi kapan dan di mana rumah dan factor - faktor pendidikan di sekitar mereka ditampilkan secara positif untuk mendorong membantu orang lain sebagai cara mengurangi konflik seperti intimidasi, diskriminasi, kekerasan, dll. Temuan ini studi mungkin memiliki implikasi penting untuk pengembangan kurikulum, pelatihan guru dan pengembangan materi pembelajaran.

\section{SIMPULAN DAN SARAN \\ Simpulan}

Artikel ini memberikan petunjuk tentang mekanisme potensial antara empati dan prososial perilaku pada anak-anak kelas atas. Saya mengamati bagaimana anak-anak terpapar dengan masalah dunia nyata melalui rangsangan visual (video), dan bagaimana mereka merespons dengan berbagai ekspresi emosional. Beberapa menjadi sangat emosional, sementara yang lain tampak tidak tersentuh atau hanya berusaha menyembunyikannya perasaan. Respons ini tampaknya dipengaruhi oleh kepribadian anak-anak, dan / atau mereka jenis kelamin. Faktor-faktor ini mempengaruhi ekspresi empati emosional dan kognitif. Lebih anakanak emosional atau empatik tampaknya melakukan upaya yang lebih besar untuk mengidentifikasi diri dengan para korban (situasi dan perasaan). Gender juga tampaknya menjadi faktor yang mengurangi emosi anak-anak dan kognisi. Selain itu, selama tahap empati kognitif, fasilitatorpeneliti memainkan peran penting dalam membantu anak-anak memahami orang lain. Pemahaman tentang relevansi masing masing masalah dunia nyata akhirnya diterjemahkan ke dalam niat prososial yang dinyatakan. Dengan kata lain, ini adalah contoh bagaimana empati anak-anak kemudian dapat memutuskan arah proses (lain). Itu realisasi niat prososial, bagaimanapun, terikat pada setiap resolusi positif potensial hambatan. 


\section{Saran}

Dari temuan artikel ini, betapa bersemangatnya anak - anak tentang kemungkinan itu memberikan bantuan kepada orang lain tampaknya merupakan fitur penting. Anak - anak perlu diwaspadai masalah, memiliki tanggung jawab internal untuk membantu, dan menyatakan keyakinan bahwa akting akan mengarah ke hasil yang diinginkan. Data mendukung gagasan bahwa berbagai faktor eksternal memperkuat perasaan kemanjuran individu.

\section{DAFTAR RUJUKAN}

Arwani. (2002). Komunikasi dalam Keperawatan. Jakarta: EGC

Baron, R.A, \& Byrne, D. (2005) . Psikoloi Sosial edisi 10. Jakarta: Erlangga.

Catherine, N. L. A., \& Schonert-Reichl, K. A. (2010) Children's perceptions and comforting strategies to infant crying: Relations to age, sex, and empathyrelated responding. British Journal of Developmental Psychology, 29, 524551.

Goleman, D. (2002). Emotional intelligence : Kecerdasan emosional mengapa EI lebih penting daripada IQ. Alih Bahasa T. Hermaya. Jakarta:P.T Gramedia Pustaka Utama 